\title{
A Distinct Subgroup of Small DRG Cells Express GDNF Receptor Components and GDNF Is Protective for These Neurons after Nerve Injury
}

\author{
David L. H. Bennett, ${ }^{1}$ Gregory J. Michael, ${ }^{2}$ Navin Ramachandran, ${ }^{1}$ John B. Munson, ${ }^{3}$ Sharon Averill, ${ }^{2}$ \\ Qiao Yan, ${ }^{4}$ Stephen B. McMahon, ${ }^{1}$ and John V. Priestley ${ }^{2}$
}

'Department of Physiology, United Medical and Dental Schools (St. Thomas' Campus), London, SE1 7EH, United Kingdom, 2Department of Anatomy, Queen Mary and Westfield College, London, E1 4NS, United Kingdom, ${ }^{3}$ Department of Neuroscience, University of Florida College of Medicine, Gainsville, Florida 32610, and ${ }^{2}$ Department of Neuroscience, Amgen Inc., Thousand Oaks, California 91320

\begin{abstract}
Several lines of evidence suggest that neurotrophin administration may be of some therapeutic benefit in the treatment of peripheral neuropathy. However, a third of sensory neurons do not express receptors for the neurotrophins. These neurons are of small diameter and can be identified by the binding of the lectin IB4 and the expression of the enzyme thiamine monophosphatase (TMP). Here we show that these neurons express the receptor components for glial-derived neurotrophic factor (GDNF) signaling (RET, GFR $\alpha-1$, and GFR $\alpha-2)$. In lumbar dorsal root ganglia, virtually all IB4-labeled cells express RET mRNA, and the majority of these cells (79\%) also express GFR $\alpha-1$, GFR $\alpha-2$, or GFR $\alpha-1$ plus GFR $\alpha-2$.
\end{abstract}

In the adult animal, specific dorsal root ganglion (DRG) cell populations require particular neurotrophins for their phenotypic maintenance (Verge et al., 1996). The trk receptors in general are expressed in a nonoverlapping manner by sensory neurons in combination with the low-affinity neurotrophin receptor p75 (Wright and Snider, 1995). Large diameter DRG cells mostly possess myelinated axons and respond principally to low threshold stimuli. These neurons express trkB or trkC or both (McMahon et al., 1994). Small diameter DRG cells, in contrast, have unmyelinated axons and are principally nociceptors and thermoceptors. Half of this group (40\% of total DRG cells) constitutively synthesize neuropeptides and express trkA (Averill et al., 1995; Molliver et al., 1995). The other half of the small diameter DRG cells (35\% of total DRG cells) possess cell surface glycoconjugates that can be identified by binding of the lectin Isolectin B4 from Griffonia simplicifolia (IB4) (Silverman and Kruger, 1990). They also express the enzyme thiamine monophosphatase (TMP). During development these cells are dependent on NGF for survival (Silos-Santiago et al., 1995). During the postnatal

\footnotetext{
Received Dec. 8, 1997; revised Jan. 23, 1998; accepted Jan. 28, 1998.

This work was funded by the Medical Research Council of Great Britain. D.L.H.B. is supported by the Special Trustees of Guy's and St. Thomas' Hospitals. We acknowledge the expert technical assistance of C. Abel and S. Hamilton. We also thank Genentech for the provision of rhNGF and Amgen for the provision of rhGDNF; H. S. Phillips and R. D. Klein for the provision of the GFR $\alpha-2$ sequence; and Dr. D. O. Clary, Dr. T. Görcs, and Professor J. M. Polak for the provision of the trkA, somatostatin, and CGRP antisera, respectively.

D.L.H.B. and G.J.M. contributed equally to this work.

Correspondence should be addressed to Professor S. B. McMahon, Department of Physiology, St. Thomas' Hospital Medical School, Lambeth Palace Road, London SE1 7EH, UK.

Copyright (C) 1998 Society for Neuroscience $\quad 0270-6474 / 98 / 183059-14 \$ 05.00 / 0$
}

GDNF, but not nerve growth factor (NGF), can prevent several axotomy-induced changes in these neurons, including the downregulation of IB4 binding, TMP activity, and somatostatin expression. GDNF also prevents the slowing of conduction velocity that normally occurs after axotomy in a population of small diameter DRG cells and the A-fiber sprouting into lamina II of the dorsal horn. GDNF therefore may be useful in the treatment of peripheral neuropathies and may protect peripheral neurons that are refractory to neurotrophin treatment.

Key words: IB4; trkA; RET; somatostatin; GFR $\alpha-1$; GFR $\alpha-2$; axotomy; C-fibers; nociception; pain; sprouting; spinal cord

period, however, these cells downregulate trkA expression (Bennett et al., 1996a; Molliver and Snider, 1997). It is this population that in the adult does not express detectable levels of the lowaffinity neurotrophin receptor p75 nor any known trk receptor (McMahon et al., 1994; Averill et al., 1995; Molliver et al., 1995; Wright and Snider, 1995). In this study we have examined the possibility that GDNF exerts a trophic action on these neurons.

GDNF is a member of the transforming growth factor- $\beta$ (TGF- $\beta$ ) superfamily (Lin et al., 1993) and is related to neurturin (Kotzbauer et al., 1996). GDNF has been demonstrated to have potent survival-promoting effects on midbrain dopaminergic neurons (Beck et al., 1995; Bowenkamp et al., 1995) and motoneurons (Henderson et al., 1994; Oppenheim et al., 1995; Yan et al., 1995). There is growing evidence that GDNF can have a trophic action on sensory neurons. In GDNF-deficient mice there is a significant reduction in the number of spinal sensory neurons (Moore et al., 1996). During the late embryonic and postnatal period, the survival of a subpopulation of DRG cells is supported by this factor in vitro (Buj-Bello et al., 1995), and those neurons that are supported are IB4 binding (Molliver et al., 1997). GDNF can also prevent the death of axotomized developing sensory neurons in vivo (Matheson et al., 1997).

The receptor for GDNF is thought to be a complex of GFR $\alpha-1$ (Jing et al., 1996, Treanor et al., 1996; GFR $\alpha$ Nomenclature Committee, 1997), which acts as a ligand binding domain, and RET, which acts as the signal transducing domain (Durbec et al., 1996, Trupp et al., 1996). Neurturin also appears to use RET for signaling, but operates via another GPI-linked binding protein termed GFR $\alpha$-2 (Baloh et al., 1997; Buj-Bello et al., 1997; GFR $\alpha$ Nomenclature Committee, 1997; Klein et al., 1997). GDNF may 
also be able to act via GFR $\alpha$-2, particularly in the presence of RET (Sanicola et al., 1997). In this study, we have examined the expression of these GDNF receptor subunits within adult sensory neurons.

One means of studying the trophic requirements of different subgroups of sensory neurons has been to determine to what extent injury-induced changes can be reversed by the administration of exogenous trophic factors (Verge et al., 1995, 1996). The second aim of the present work was to investigate the efficacy of GDNF in reversing such axotomy-induced changes in adult sensory neurons.

\section{MATERIALS AND METHODS}

Animal surgery. Adult male Wistar rats underwent unilateral sciatic nerve section combined with an intrathecal infusion of recombinant human GDNF (rhGDNF), rhNGF or control buffer. The sciatic nerve was exposed under pentobarbitone anesthesia $(40 \mathrm{mg} / \mathrm{kg}$, i.p., with sterile precautions) and ligated $20 \mathrm{~mm}$ distal to the obturator tendon. Concurrently a small laminectomy was performed between L6 and S1 vertebrae, and the dura was cut. A SILASTIC tube of $0.6 \mathrm{~mm}$ outer diameter was introduced intrathecally so that its tip lay at the level of the lumbar enlargement of the spinal cord. The intrathecal tubing was attached to an Alzet miniosmotic pump (type 2002; Alzet, Alza Corporation, Palo Alto, CA) delivering at a rate of $0.5 \mu \mathrm{l} / \mathrm{hr}$. Animals received either a control infusion ( $n=4$; saline with rat serum albumin, $1 \mathrm{mg} / \mathrm{ml})$ or this vehicle plus rhGDNF ( $n=4$ at $12 \mu \mathrm{g} / \mathrm{d} ; n=3$ at $1.2 \mu \mathrm{g} / \mathrm{d})$ or $\mathrm{rhNGF}$ $(n=3$ at $12 \mu \mathrm{g} / \mathrm{d} ; n=3$ at $1.2 \mu \mathrm{g} / \mathrm{d})$. Another group of animals underwent axotomy with either control infusion $(n=4)$ or GDNF treatment $(n=4$ at $12 \mu \mathrm{g} / \mathrm{d} ; n=3$ at $1.2 \mu \mathrm{g} / \mathrm{d})$. Twelve days later the left sciatic nerve was re-exposed and injected with $4 \mu \mathrm{l}$ of $1 \%$ B-subunit of cholera toxin (CTB) (List Biological Labs, Campbell, CA) in distilled water, using a micropipette glued to a Hamilton syringe. Animals were perfused with heparinized saline followed by $4 \%$ paraformaldehyde $14 \mathrm{~d}$ after sciatic section. Another group of normal animals $(n=5)$ was labeled with $\mathrm{CTB}$ in the same manner but did not undergo sciatic axotomy. After perfusion the left and right L4 and L5 DRGs were removed as well as L3-L6 segments of the spinal cord. Pins were placed in the right side of the spinal cord at the border between L3/L4, L4/L5, and L5/L6 to ease identification of the spinal levels during analysis. Tissues were post-fixed in $4 \%$ paraformaldehyde for $2 \mathrm{hr}$, after which they were transferred to $15 \%$ sucrose overnight. One group of animals $(n=4)$ was perfused in the same manner and used for in situ hybridization. Another group of naive animals $(n=3)$ was used to provide control values for IB4, somatostatin, calcitonin gene-related peptide (CGRP), and TMP staining.

Electrophysiological analysis was performed on five different groups of animals: normal intact animals $(n=4)$; animals in which the tibial nerve had been cut and tied 2 weeks previously and with an intrathecal cannula delivering $1 \mathrm{mg} / \mathrm{ml}$ normal rat serum albumin in saline at $12 \mu \mathrm{l} / \mathrm{d}(n=5)$; animals with tibial nerve axotomy and continuous intrathecal delivery of rhGDNF $(12 \mu \mathrm{g} / \mathrm{d} ; n=3)$, rhNGF $(12 \mu \mathrm{g} / \mathrm{d} ; n=3)$, or rhGDNF and rhNGF $(12 \mu \mathrm{g} / \mathrm{d}$ each; $n=4)$. This surgery was performed under pentobarbitone anesthesia and with sterile precautions.

Staining procedures. Sections of DRG and spinal cord were cut at a thickness of 15 and $20 \mu \mathrm{m}$, respectively. Sections of DRG were cut serially onto slides so that each slide contained an ordered series of sections throughout the ganglia, at a separation of at least $150 \mu \mathrm{m}$ between sections. When the spinal cord was cut, every fifth section was mounted serially onto slides. Every slide therefore had a series of sections through the L4 and L5 region of spinal cord at a separation of at least 800 $\mu \mathrm{m}$ between sections. For immunostaining, primary antisera were rabbit anti-CGRP (1:2000, gift of Professor J. M. Polak), rabbit antisomatostatin (1:2000, gift of Dr. T. Görcs), goat anti-CTB (1:2000, List), and biotinylated IB4 $(10 \mu \mathrm{g} / \mathrm{ml}$, Sigma). Secondary antisera were FITCor TRITC-conjugated anti-rabbit or anti-goat $\operatorname{IgG}(1: 200$, Jackson labs) or FITC-conjugated Extr-Avidin (1:200, Sigma). Histochemistry for TMP was also performed as described previously (McMahon, 1986).

Analyses of colocalization of RET immunoreactivity with other DRG products were performed on $8 \mu \mathrm{m}$ cryostat sections using dual-labeling immunofluorescence. The production and staining characteristics of the RET antiserum have already been described (Molliver et al., 1997). RET immunostaining was combined sequentially with markers described above as well as sheep anti-CGRP (1:2000, Affiniti) and anti-rabbit trkA
(Averill et al., 1995). Indirect tyramide signal amplification (TSA, New England Nuclear) was used for the first reaction when staining with two rabbit antisera as described previously (Michael et al., 1997). The lack of cross-reactivity is thought to be caused by the fact that the primary antiserum is highly diluted compared with when it is used in indirect immunofluorescence without amplification (e.g., trkA 1:100,000 vs 1:4000), and therefore the second series reactions do not detect it. This was verified by a lack of staining in control single-labeled preparations using indirect immunofluorescence and the antiserum dilutions used for TSA.

For combined fluorescence histochemistry with in situ hybridization, cryostat sections $(6-8 \mu \mathrm{m})$ were cut and thaw-mounted onto Superfrost Plus slides (BDH Chemicals, Poole, UK). Immunocytochemistry and/or lectin binding histochemistry was performed before in situ hybridization (Michael and Priestley, 1996b; Michael et al., 1997). Sections were incubated for $40-48 \mathrm{hr}$ at room temperature with trkA antibody (4 $\mu \mathrm{g} / \mathrm{ml})$, N52 monoclonal antibody to phosphorylated heavy chain neurofilament $(1: 400$, Sigma), or biotinylated IB4 $(10 \mu \mathrm{g} / \mathrm{ml})$ diluted in diethylpyrocarbonate (DEPC)-treated PBS containing $0.2 \%$ Triton $\mathrm{X}-100,0.1 \%$ sodium azide, $0.5 \mathrm{~mm}$ dithiothreitol, and $100 \mathrm{U} / \mathrm{ml}$ RNasin (Promega, Madison, WI). Lectin binding buffer also contained $0.1 \mathrm{~mm}$ $\mathrm{MnCl}_{2}, 0.1 \mathrm{~mm} \mathrm{MgCl}$, and $0.1 \mathrm{mM} \mathrm{CaCl}_{2}$. Sections were washed in DEPC PBS and incubated for $4 \mathrm{hr}$ in tetramethyl rhodamine isothiocyanate (TRITC)-conjugated secondary antibodies (1:200, Jackson Laboratory, Bar Harbor, ME) or fluorescein isothiocyanate (FITC)-conjugated Extr-Avidin (1:200, Sigma) diluted in the same buffer without added divalent cations. After additional washes in DEPC PBS, sections were processed through prehybridization steps, hybridized to ${ }^{35}$ S-dATP endlabeled oligonucleotides, and washed as described previously (Michael and Priestley, 1996a). Slides were dipped in autoradiographic emulsion (Amersham, Arlington Heights, IL) and developed after 4-6 weeks. After the slides were coverslipped with PBS glycerol (1:3 containing $2.5 \%$ 1,4-diazobicyclo-(2,2,2)-octane), fluorescent labeling and silver grains were visualized using epifluorescence microscopy combined with either epipolarized illumination or dark-field illumination. The oligonucleotides used for probes were complementary to nucleotides 996-1029 of the rat GFR $\alpha-1$ sequence (Jing et al., 1996) and nucleotides 161-194 of the rat RET sequence (Canzian et al., 1995), and for GFR $\alpha-2$ the oligonucleotide sequence cctggactgatgtttgtcgtgagctctgtgaagc was used (Klein et al., 1997).

Controls for the specificity of in situ hybridization included adding a 100 -fold excess of unlabeled oligonucleotide to hybridization buffer, which effectively competed all specific binding of radiolabeled probe. Use of the GFR $\alpha-1$, GFR $\alpha-2$, and RET to label sections of rat brain yielded patterns of hybridization identical to reported patterns (Trupp et al., 1997) (our unpublished observations). All probes were synthesized to be of the same size and $\mathrm{G}+\mathrm{C}$ base content and produced reproducible and characteristic patterns of labeling.

Image analysis. After in situ hybridization, cells that had silver grains over the cell cytoplasm at least five times background were counted as positive. For quantitation of in situ hybridization, counts of cells labeled for RET, GFR- $\alpha 1$, and GFR $\alpha-2$ and coexpressed cell markers were conducted on ganglia from at least four animals, with separation between analyzed sections being at least $100 \mu \mathrm{m}$. At least 1500 cells were counted for each probe/peptide combination. For counts of the percentage of cell profiles expressing CGRP, somatostatin, IB4 binding, and TMP activity after different treatments, six sections were randomly selected for each marker for each animal in each group. In each section the total number of cell profiles was counted using dark-field illumination, and then the number of positively stained cell profiles was counted.

For image analysis of IB4, TMP, CGRP, and CTB staining within the dorsal horn, four randomly selected sections of L4/5 spinal cord were used from each animal. Two sections were selected from L4 and two sections were selected from L5 to ensure that the analysis was not biased toward one region of the lumbar enlargement. For analysis of IB4, CGRP, and TMP staining, images of spinal cord sections were captured directly off the microscope at $25 \times$ objective magnification using a Grundig FA87 digital camera with integrating framestore. The image was then thresholded to a set level to reveal the labeling. Four boxes of size $27 \times$ $27 \mu \mathrm{m}$ were placed over lamina II of the axotomized side (within the sciatic territory) and in equivalent positions on the contralateral (i.e., intact sciatic) side of the sections. The area occupied by labeled terminals was then calculated for each box. A similar method was used for analysis of CTB staining, but in this case the four boxes were placed over lamina III of the sciatic-labeled territory and four were placed dorsal to the 
lamina III boxes in lamina II outer. The area occupied by CTB-stained terminals within each of these boxes was then calculated.

This image analysis system was similarly used for cell size distribution analyses of RET, GFR $\alpha-1$, and GFR $\alpha$-2. Images of DRG sections were captured directly off the microscope as described above. Cell profiles were outlined using a hand-held mouse from which the cell area was calculated. For the RET analysis 1128 profiles were drawn, for the GFR $\alpha-1$ analysis 990 profiles were drawn, and for the GFR $\alpha-2$ analysis 567 profiles were drawn. Cell size distribution analyses were also performed on normal L4/5 ganglia ( $n=4$ animals), axotomized ganglia $(n=$ 4 animals), and ganglia that had undergone axotomy in combination with GDNF treatment $(12 \mu \mathrm{g} / \mathrm{d} ; n=4)$. Twelve sections that had been cut at a thickness of $15 \mu \mathrm{m}$ and stained with toluidine blue were selected for each animal. The selected section was then divided into quadrants, and all the profiles within a randomly selected quadrant were outlined. In total 2033 profiles were drawn in the normal group, 2256 in the axotomy group, and 1875 in the axotomy plus GDNF group.

Trophic factor effects on electrophysiological properties of axotomized $C$-fibers. As an independent measure of the efficacy of trophic factors, we studied the electrophysiological properties of damaged C-fibers. The conduction velocity $(\mathrm{CV})$ distribution of $\mathrm{C}$-fibers projecting through the tibial nerve was measured in urethane-anesthetized animals $(1.25 \mathrm{gm} / \mathrm{kg}$, i.p.) in terminal experiments. Fine strands of the L5 dorsal root were dissected and mounted on recording electrodes. The tibial nerve was continuously electrically stimulated at $2 \mathrm{~Hz}$ with square wave current pulses: $5 \mathrm{~mA}, 1 \mathrm{msec}$. The evoked activity on the root filament was amplified and filtered by conventional means, and the averages of 64-128 responses were constructed (see Fig. 9). In these averages it was possible to determine the latency of individual fibers. All fibers conducting at less than $2 \mathrm{~m} / \mathrm{sec}$ were included in analysis. Typically 3-10 C-fibers were found in each strand. A sample of approximately 50 individual C-fibers was measured in each animal, from which the conduction velocity distribution was computed. Distributions from three to five animals in each experimental group were averaged and plotted as cumulative sums (e.g., see Fig. 9). The distributions of CVs were statistically compared using the Kolmogorov-Smirnov test.

\section{RESULTS}

\section{GDNF receptor expression within sensory neurons}

Abundant labeling for RET, GFR $\alpha-1$, and GFR $\alpha-2$ mRNAs was observed in lumbar DRG cells (Fig. 1), with $64 \pm 4.4,40.6 \pm 1.5$, and $32.8 \pm 1.0 \%$ of DRG cell profiles labeled, respectively. Cells of all sizes showed labeling, but GFR $\alpha-2$ and RET mRNAs were expressed by proportionally more small and intermediate-sized cells (Figs. 1, 2).

To identify the cell types that were labeled, in situ hybridization was combined with immunocytochemistry for markers that are widely used to characterize three main DRG subpopulations (Averill et al., 1995). Strikingly, a high level of expression of all three GDNF receptor components (RET, GFR $\alpha$ - 1 , and GFR $\alpha-2$ ) was found in cells labeled with the lectin IB4 (Fig. 2, Table 1), a marker for small neurons that do not express any of the trk receptors (Averill et al., 1995; Molliver et al., 1995). In the case of RET, virtually all IB4 cells express RET mRNA (95\%), and the IB4 cells account for a very high percentage of the RET population (79\%) (Table 1). In contrast to RET, GFR $\alpha-1$ and GFR $\alpha-2$ mRNAs are each expressed in only approximately half of the IB4 cells (46 and 55\%, respectively) (Table 1). To determine whether GFR $\alpha-1$ and GFR $\alpha-2$ are expressed by the same IB 4 cells, serial sections were triple-labeled for trkA, IB4, and GFR $\alpha-1$ or GFR $\alpha-2$ mRNAs (Fig. 3). This analysis revealed that the RET/IB4 cells can be subdivided into four, roughly equally sized subgroups, based on their expression of the GFR $\alpha$ subunits: GFR $\alpha-1$ alone (21\% of IB4 cells), GFR $\alpha-2$ alone (28\%), both GFR $\alpha-1$ and GFR $\alpha-2$ (30\%), and neither GFR $\alpha-1$ nor $\operatorname{GFR} \alpha-2(21 \%)$.

In contrast to the high expression of GDNF receptor components in the IB4 cells, expression was low in the second subpopu-
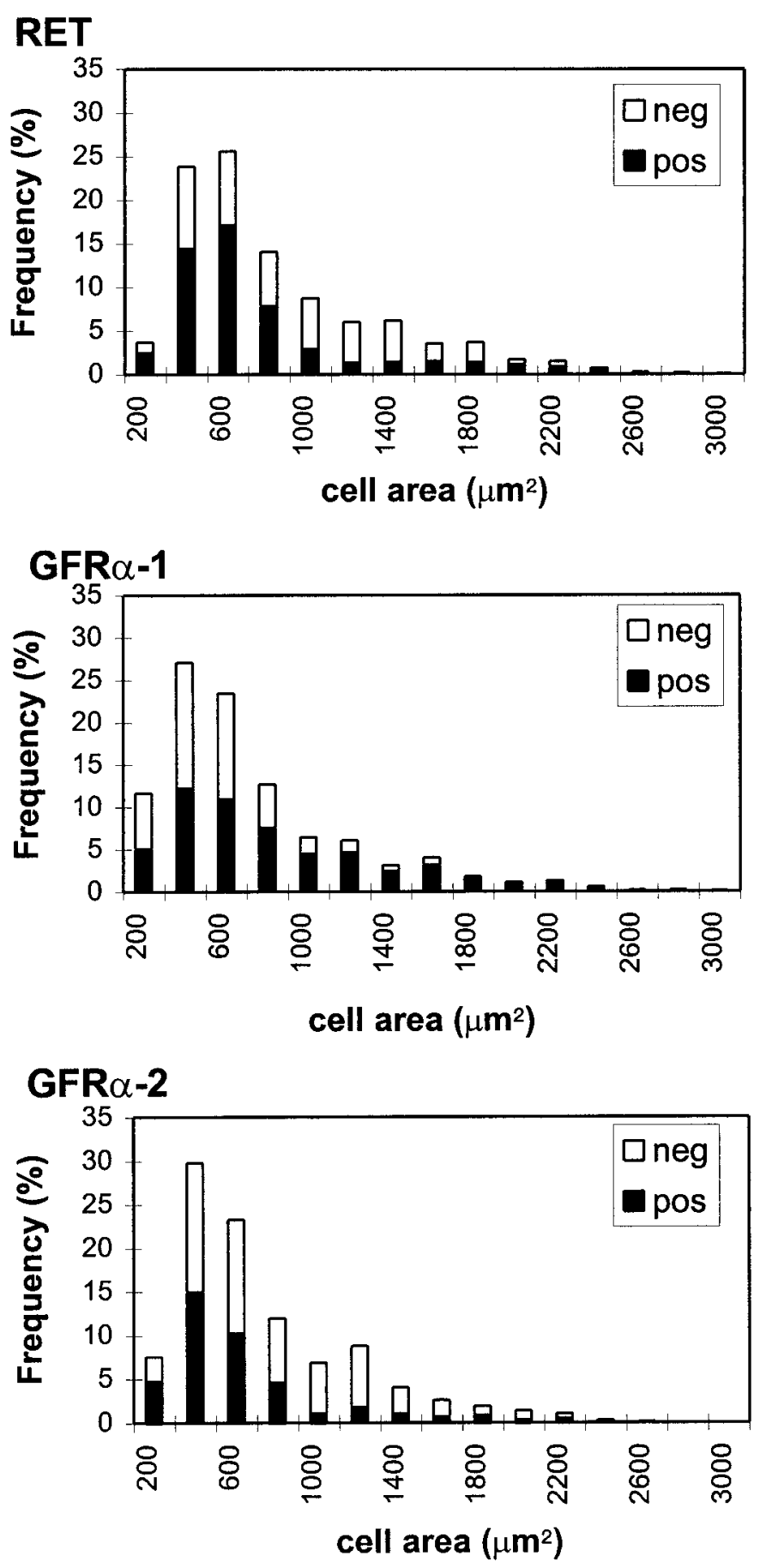

Figure 1. Cell size distribution of DRG cell profiles positively and negatively labeled for RET, GFR $\alpha-1$, and GFR $\alpha$ - 2 within L4/5 dorsal root ganglia. RET and GFR $\alpha-2$ are present predominantly in small and intermediate diameter DRG cell profiles but are also present in some large diameter DRG cell profiles. GFR $\alpha-1$ is more evenly distributed through the whole cell size spectrum.

lation of DRG cells, namely the trkA immunoreactive cells. GFR $\alpha-2$ mRNA was observed in very few trkA immunoreactive cells (3\%) (Table 1), and although RET mRNA was expressed by a significant number of trkA cells $(28 \%)$ (Table 1$)$, they belonged to a group that also showed IB4 labeling (Table 1). The majority of trkA cells do not show IB4 labeling (Averill et al., 1995; Michael et al., 1997) and did not express either RET or GFR $\alpha-2$ 

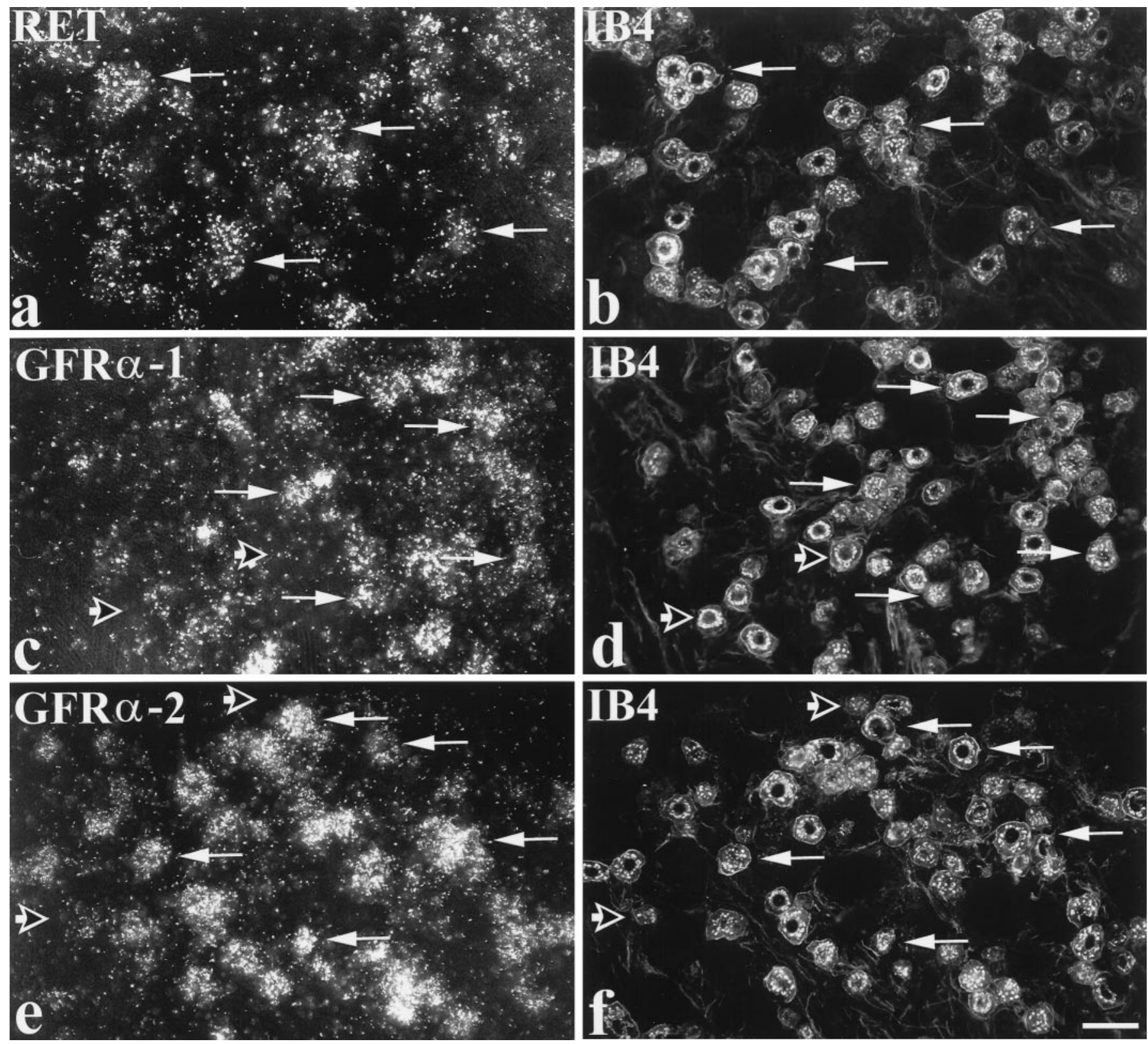

Figure 2. Expression of RET, GFR $\alpha$-1, and GFR $\alpha$-2 in IB4-labeled DRG cells. In situ hybridization for RET (a), GFR $\alpha$-1 (c), or GFR $\alpha-2$ (e) was combined with IB4 labeling $(b, d, f)$. $a$ and $b$ show that many IB4 cells express RET (arrows indicate double-labeled cells). A similar pattern is seen in $c$ and $d$ and in $e$ and $f$ in relation to GFR $\alpha-1$ and GFR $\alpha$-2, except that the GFR $\alpha$ components are expressed in a smaller proportion of IB4 cells. Long arrows indicate IB4-labeled cells that express GFR $\alpha-1$ or GFR $\alpha$-2, whereas short open arrows indicate IB4 cells that do not express GFR $\alpha-1$ or GFR $\alpha$-2. Scale bar, $50 \mu \mathrm{m}$.

mRNAs (Table 1). However, a small number of these cells do express GFR $\alpha-1$ mRNA (Table 1). The GDNF receptor components were also expressed in the third subpopulation of DRG cells, namely large neurons that can be identified by labeling with anti-neurofilament antisera such as N52. GFR $\alpha-1$ and RET mRNAs are expressed by a significant number of N52 immunoreactive cells (40 and 33\%, respectively) (Table 1), but GFR $\alpha-2$ is virtually absent (only 5\% of N52 cells).

To further study the pattern of RET expression, a polyclonal antiserum to RET was used (Molliver et al., 1997). Staining of L4/5 DRG sections (Fig. 4) revealed immunoreactivity in a population of DRG cells similar to that labeled by in situ hybridization. Thus $72 \%$ of L4/5 DRG cell profiles were RET immunoreactive, and of these the majority were also IB4labeled (96\% of IB4 cells were RET immunoreactive) (Fig. 4). Only 27 and $30 \%$, respectively, of RET immunoreactive cells showed immunoreactivity for trkA or for the neuropeptide CGRP (Fig. 4). The distribution of RET immunoreactivity in the lumbar enlargement of the spinal cord was also studied. RET immunoreactive terminals were present principally in lamina IIi (Fig. 4), the same region in which IB4 labeling is observed (Fig. 4). It was interesting, given that some large diameter DRG cells express RET (see above), that clear labeling for RET immunoreactive terminals was not observed in the regions of the spinal cord where these neurons terminate, i.e., the deep dorsal horn or the ventral horn. 
Table 1. Percentage of DRG neurons co-expressing immunoreactivity for trkA, IB4, trkA + IB4, or N52 and in situ hybridization signal for RET, GFR $\alpha-1$, and GFR $\alpha-2$ mRNAs

\begin{tabular}{|c|c|c|c|c|c|c|}
\hline & \multicolumn{2}{|l|}{ RET mRNA } & \multicolumn{2}{|l|}{ GFR $\alpha-1$ mRNA } & \multicolumn{2}{|l|}{ GFR $\alpha-2$ mRNA } \\
\hline & $\begin{array}{l}\% \text { RET } \\
\text { expressing other }\end{array}$ & $\begin{array}{l}\% \text { other } \\
\text { expressing RET }\end{array}$ & $\begin{array}{l}\% \text { GFR } \alpha-1 \\
\text { expressing other }\end{array}$ & $\begin{array}{l}\% \text { other } \\
\text { expressing GFR } \alpha-1\end{array}$ & $\begin{array}{l}\% \text { GFR } \alpha-2 \\
\text { expressing other }\end{array}$ & $\begin{array}{l}\% \text { other } \\
\text { expressing GFR } \alpha-2\end{array}$ \\
\hline TrkA & $15.0 \pm 0.8$ & $27.7 \pm 2.2$ & $17.9 \pm 1.2$ & $18.0 \pm 1.0$ & $2.8 \pm 0.4$ & $2.9 \pm 0.4$ \\
\hline IB4 & $78.7 \pm 1.1$ & $95.3 \pm 0.3$ & $49.5 \pm 1.0$ & $46.0 \pm 3.6$ & $78.3 \pm 1.8$ & $54.5 \pm 0.6$ \\
\hline TrkA + IB4 & $13.5 \pm 2.2$ & $77.0 \pm 8.4$ & $2.5 \pm 0.5$ & $12.7 \pm 1.5$ & $2.1 \pm 0.6$ & $9.2 \pm 2.3$ \\
\hline N52 & $25.8 \pm 3.3$ & $33.0 \pm 2.0$ & $40.0 \pm 3.8$ & $40.0 \pm 2.0$ & $16.7 \pm 1.7$ & $5.0 \pm 0.4$ \\
\hline
\end{tabular}
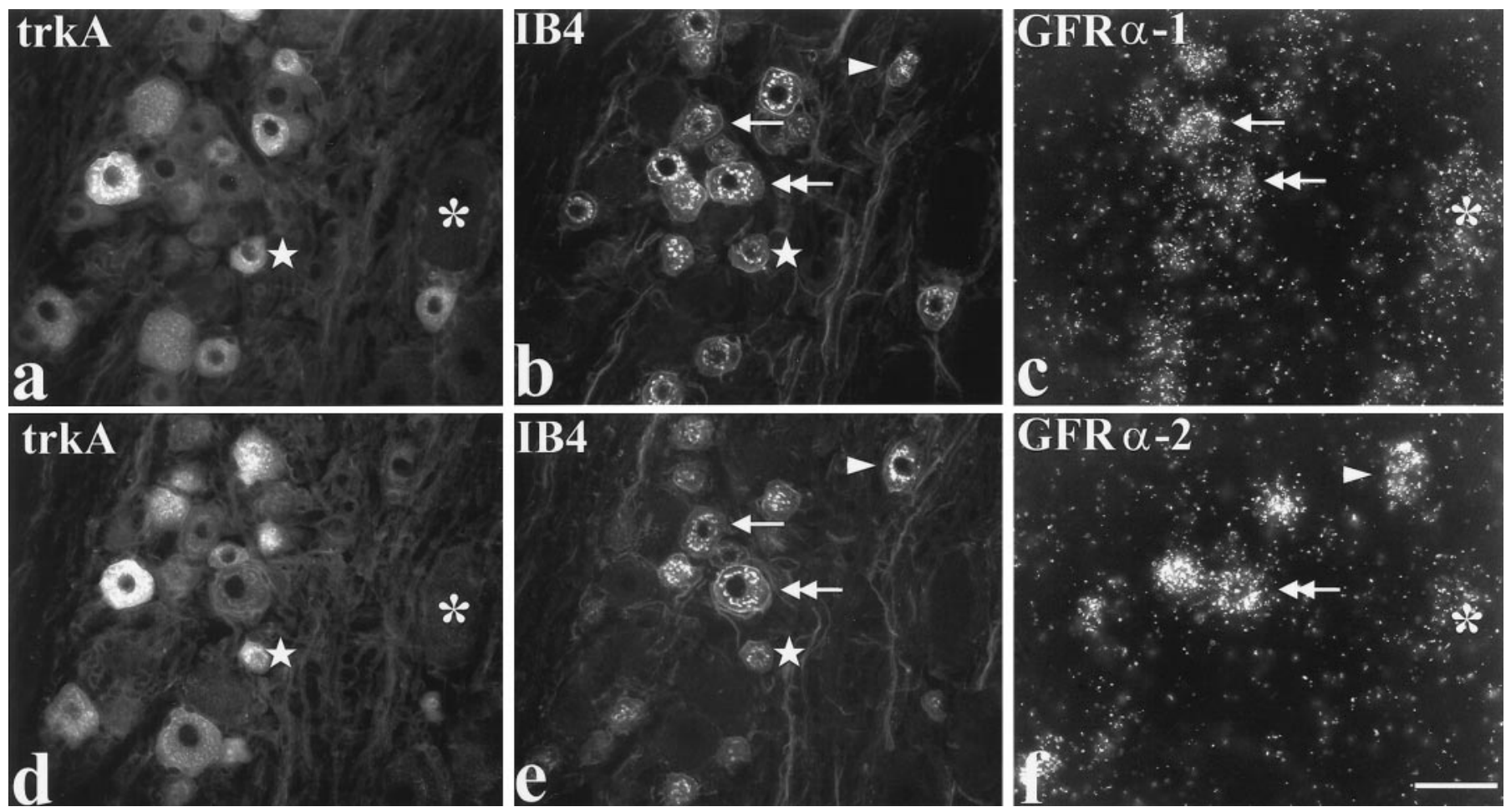

Figure 3. GFR $\alpha-1$ and GFR $\alpha-2$ expression in IB4 cells. GFR $\alpha-1$ and GFR $\alpha-2$ are coexpressed in one group of IB4 cells, expressed separately in other groups, and not expressed at all in a fourth group. Serial sections are shown triple-labeled for trkA $(a, d)$, IB4 $(b, e)$, and either GFR $\alpha-1(c)$ or GFR $\alpha-2$ $(f)$ mRNAs. A IB4 cell expressing only GFR $\alpha-1$ is identified by an arrow. An arrowhead indicates a IB4 cell that expresses only GFR $\alpha$-2. The double arrow indicates a IB4 cell that expresses both GFR $\alpha-1$ and GFR $\alpha-2$. Note that none of these cells are trkA immunoreactive. The star indicates a IB4 cell that expresses neither GFR $\alpha$-1 nor GFR $\alpha$-2. This cell is also trkA immunoreactive. Also shown is a large cell (asterisk) that expresses both GFR $\alpha$ - 1 and GFR $\alpha$-2. It is not IB4-labeled or trkA immunoreactive. Scale bar, $50 \mu \mathrm{m}$.

\section{GDNF reverses axotomy-induced changes in the IB4-binding population of sensory neurons}

To investigate the trophic effects of GDNF on sensory neurons, the ability of GDNF and NGF to reverse axotomy-related changes in different populations of sensory neurons was compared. Two different doses of these factors were used: a low dose of $1.2 \mu \mathrm{g} / \mathrm{d}$ and a high dose of $12 \mu \mathrm{g} / \mathrm{d}$ administered continuously over $14 \mathrm{~d}$ (these doses were based on our own and others previous findings) (Bennett et al., 1996b, Verge et al., 1995), and because these proteins are being administered in vivo, these doses are much higher than would be considered appropriate in vitro.

There were marked phenotypic changes in the IB4-binding population of small diameter DRG cells after 2 weeks of axotomy, including a reduction in the percentage of DRG cell profiles that bind IB4, from $\sim 40 \%$ to $<20 \%$ (Fig. 5, Table 2). Intrathecal application of low-dose GDNF significantly increased the number of DRG cell profiles binding IB4 after axotomy ( $p<$
0.001 ; unpaired $t$ test), and the high-dose GDNF treatment was even more effective ( $p<0.001$; unpaired $t$ test) (Fig. 5, Table 2). In contrast, intrathecal application of NGF (at either dose) had no significant effect on this marker (Fig. 5, Table 2). TMP is an enzyme present principally in the IB4-binding "trk-less" population of DRG cells. A histochemical reaction was used to reveal TMP activity within DRG cells, and this produced a black reaction product within the cytoplasm of cells. Axotomy led to a large reduction in the proportion of DRG cell profiles that expressed TMP activity (Fig. 5, Table 2). Intrathecal administration of GDNF at a low dose produced a significant increase in the proportion of cell profiles expressing TMP activity compared with no treatment ( $p<0.05$; unpaired $t$ test) (Table 2$)$. Intrathecal administration of GDNF at a high dose after axotomy was even more effective ( $p<0.001$; unpaired $t$ test) (Fig. 5, Table 2) and restored TMP activity to a level not significantly different from normal. Intrathecal administration of NGF (at either dose) 

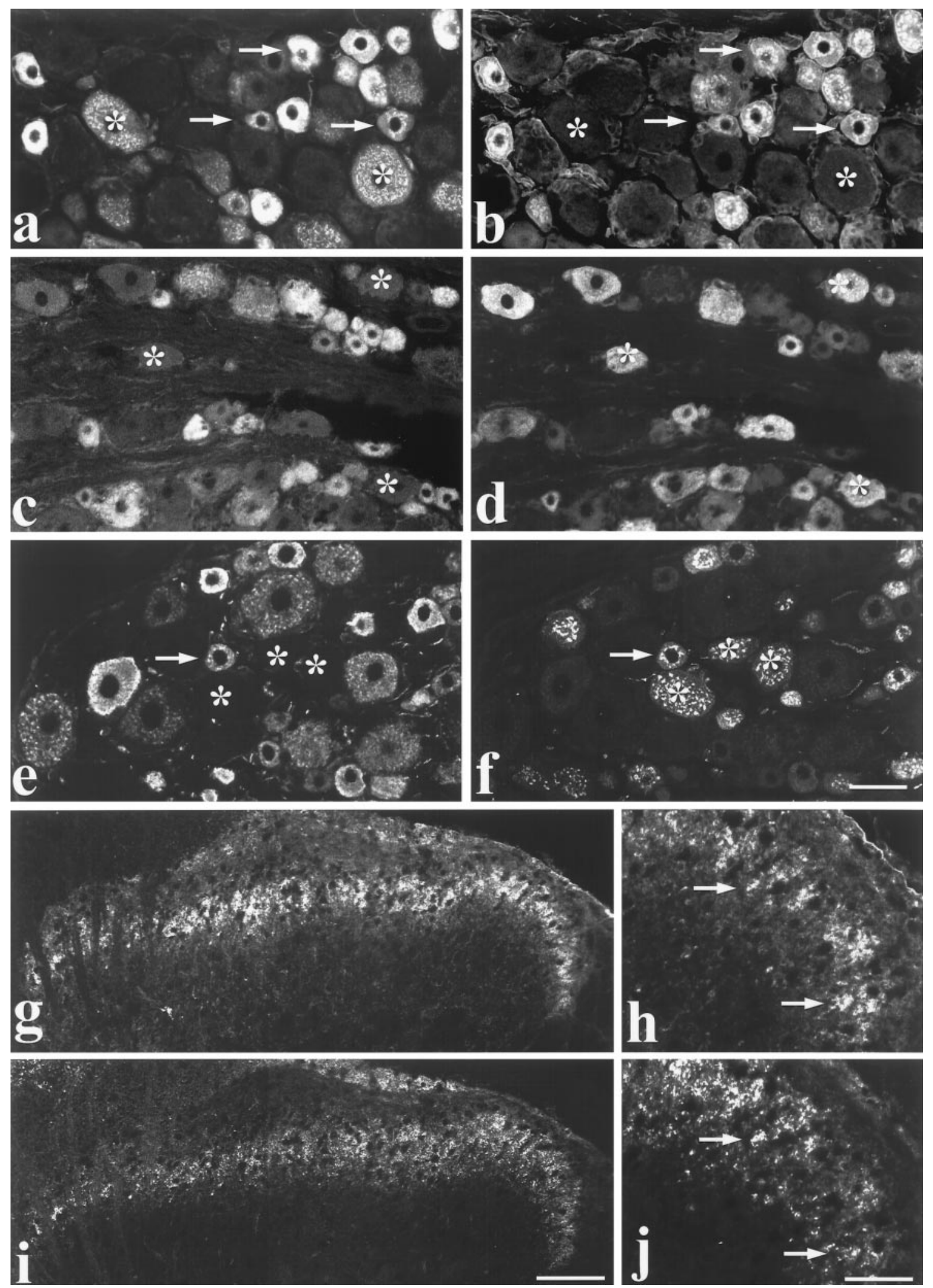

Figure 4. Colocalization of RET immunoreactivity with neurochemical markers in DRG cells and spinal cord. $a-f$, Dual labeling showing RET immunofluorescence $(a, c, e)$ combined with IB4 labeling $(b)$, trkA immunofluorescence $(d)$, and CGRP immunofluorescence $(f)$ in DRG cells. Arrows indicate extensive colocalization of RET and IB4 in small diameter cells $(a, b)$. Note that all IB4 cells show RET immunoreactivity. However, several RET positive cells do not bind IB4 (asterisks). RET labeling is not evident in many trkA cells $(c, d)$. Asterisks denote trkA cells that are not co-labeled for RET. Similarly, few CGRP-expressing DRG cells are RET immunoreactive $(e, f)$. Asterisks indicate cells that do not express RET but are labeled for CGRP. The arrow indicates a cell that is dual-labeled. $g-j$, Low-magnification $(g, i)$ and high-magnification $(h, j)$ micrographs showing RET immunofluorescence $(g, h)$ and IB4 $(i, j)$ double labeling in the dorsal horn of the spinal cord. Labeling is most intense in inner lamina II. Arrows in $h$ and $j$ indicate individual double-labeled axons. Scale bars (shown in $f$ ): $a-f, 50 \mu \mathrm{m}$; (shown in $i$ ): $g, i, 100 \mu \mathrm{m}$; (shown in $j$ ): $h, j, 30 \mu \mathrm{m}$. 


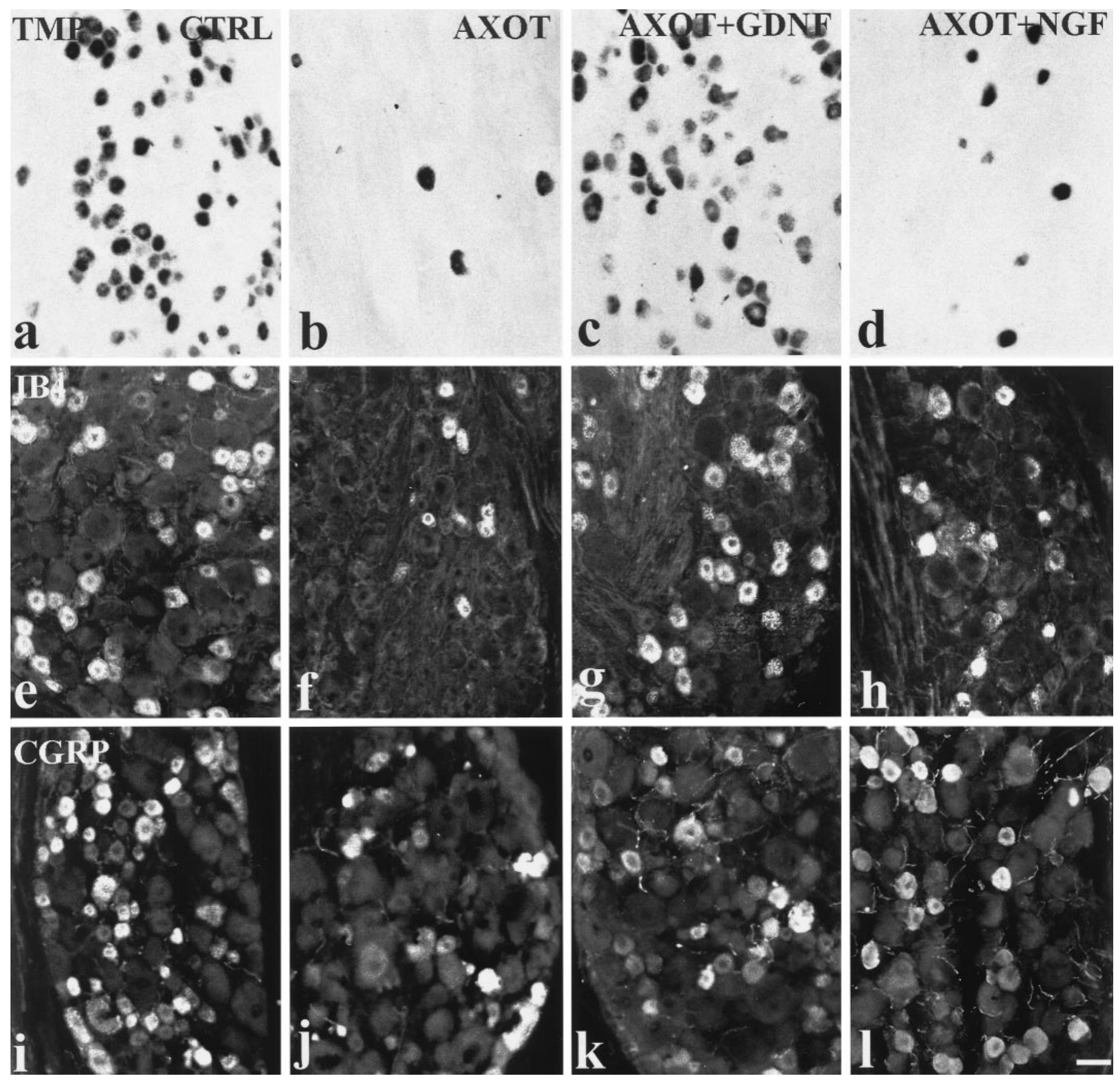

Figure 5. Histochemistry for TMP $(a-d)$, IB4 labeling $(e-h)$, and CGRP immunofluorescence $(i-l)$ in dorsal root ganglia of control animals $(a, e, i)$, animals with unilateral sciatic nerve section $(b, f, j)$, animals with unilateral sciatic nerve section combined with intrathecal GDNF treatment (12 $\mu \mathrm{g} / \mathrm{d})$ $(c, g, k)$, and animals with unilateral sciatic nerve section combined with intrathecal NGF treatment $(12 \mu \mathrm{g} / \mathrm{d})(d, h, l)$. Sciatic nerve section causes a loss of TMP $(b)$ and IB4 $(f)$ labeling, which is prevented by GDNF treatment $(c, g)$ but not by NGF $(d, h)$. In contrast, the loss of CGRP staining caused by sciatic nerve section $(j)$ is prevented by NGF $(l)$ but not by GDNF $(k)$. Scale bar, $50 \mu \mathrm{m}$. CTRL, Control; AXOT, axotomized.

was ineffective in restoring the proportion of DRG cell profiles expressing TMP activity after axotomy (Fig. 5, Table 2). Somatostatin is a neuropeptide expressed in a subgroup of trk-less DRG cells (Kashiba et al., 1996); its expression drops after axotomy (Table 2). Administration of GDNF at a low dose produced a small nonsignificant increase in the number of DRG cell profiles expressing somatostatin after axotomy. Intrathecal administration of GDNF at a high dose prevented this axotomyinduced change ( $p<0.05$; unpaired $t$ test; compared with axo- tomy alone) (Table 2). Intrathecal administration of NGF was ineffective in preventing this change (Table 2).

These effects are in contrast to those seen in the other population of small diameter DRG cells, those that express the trkA receptor and the neuropeptide CGRP. CGRP expression in DRG cell profiles fell markedly after axotomy, from $\sim 40 \%$ of cell profiles to $\sim 25 \%$. Intrathecal application of NGF at a low dose could partially prevent this reduction (Table 2). Intrathecal application of NGF at a high dose prevented this reduction $(p<$ 
Table 2. The percentage of profiles stained for IB4, TMP, CGRP, or SOM in naive animals or after axotomy alone or axotomy in combination with treatment with GDNF $(1.2$ or $12 \mu \mathrm{g} / \mathrm{d})$ or NGF $(1.2$ or $12 \mu \mathrm{g} / \mathrm{d})$

\begin{tabular}{|c|c|c|c|c|c|c|}
\hline & Naive & Axotomized & $\begin{array}{l}\text { Axotomized }+ \\
\text { GDNF } 1.2\end{array}$ & $\begin{array}{l}\text { Axotomized }+ \\
\text { GDNF } 12\end{array}$ & $\begin{array}{l}\text { Axotomized }+ \\
\text { NGF } 1.2\end{array}$ & $\begin{array}{l}\text { Axotomized }+ \\
\text { NGF } 12\end{array}$ \\
\hline IB4 & $41.1 \pm 0.7 \%$ & $19.1 \pm 1.0 \% \quad(8400)$ & $33.7 \pm 0.9 \%(7664)$ & $36.0 \pm 0.6 \% \quad(5878)$ & $20.7 \pm 1.7 \% \quad(6626)$ & $22.7 \pm 2.7 \%$ \\
\hline TMP & $36.6 \pm 0.7 \%(5446)$ & $19.6 \pm 4.7 \% \quad(8440)$ & $28.7 \pm 2.4 \%(7653)$ & $38.6 \pm 0.9 \% \quad(7751)$ & $20.4 \pm 0.5 \%$ & $20.2 \pm 0.3 \%(5657)$ \\
\hline CGRP & $40.3 \pm 0.5 \%$ & $24.5 \pm 4.3 \% \quad(6243)$ & $19.3 \pm 0.6 \%(8401)$ & $26.8 \pm 1.3 \% \quad(6732)$ & $34.6 \pm 0.9 \%$ & $38.8 \pm 0.9 \%(5380)$ \\
\hline SOM & $5.4 \pm 0.1 \%(6756)$ & $2.6 \pm 0.26 \%(5560)$ & $3.5 \pm 0.2 \%(7983)$ & $4.8 \pm 0.41 \%(5569)$ & $2.0 \pm 0.03 \%(6570)$ & $2.3 \pm 0.1 \%$ \\
\hline
\end{tabular}

The numbers in parentheses represent the total number of profiles counted. SOM, Somatostatin.

0.05; unpaired $t$ test) (Fig. 5, Table 2). Administration of GDNF (at a low dose or a high dose) had no significant effect on the proportion of DRG cell profiles expressing CGRP after axotomy (Fig. 5, Table 2).

A size analysis was performed to ensure that changes in DRG cell profile counts after different interventions did not occur as a consequence of alterations in cell size. The mean cell profile size in L4/5 ganglia in normal animals was $477 \pm 28 \mu \mathrm{m}^{2}(n=4)$, after 2 week sciatic axotomy it was $449 \pm 38 \mu \mathrm{m}^{2}(n=4)$, and after sciatic axotomy and GDNF treatment $(12 \mu \mathrm{g} / \mathrm{d} ; n=3)$ it was 494 $\pm 33 \mu \mathrm{m}^{2}$. There was no significant difference between these groups ( $p>0.2$; unpaired $t$ test).

Thus, NGF and GDNF had complementary actions in their ability to rescue phenotypic changes in trk- and non-trkexpressing small DRG neurons, respectively. We did not find any significant effects of GDNF on the percentage of DRG cells expressing IB4 and TMP in the normal DRG (data not shown).

\section{GDNF reverses a number of axotomy-induced changes within the dorsal horn of the spinal cord}

The alterations seen in DRG cell bodies were also reflected in changes within the dorsal horn after axotomy. TMP activity and IB4 binding were normally present within lamina IIi of the dorsal horn, the same region in which RET immunoreactive terminals were present (Fig. 4). After 2 weeks of axotomy, TMP activity was virtually absent from the sciatic projection territory of the dorsal horn. IB4 binding was also markedly reduced (Figs. 6, 7a). Quantitative image analysis demonstrated that continuous intrathecal administration of GDNF at a low dose had a significant effect on TMP activity and IB4 binding after axotomy $(p<0.05$; unpaired $t$ test; compared with no treatment) (Figs. 6, 7a). Administration of GDNF at a high dose was more effective and could almost completely restore TMP activity and IB4 binding levels within the dorsal horn $(p<0.001$, unpaired $t$ test, comparing GDNF treatment with axotomy alone; $p>0.2$, compared with intact) (Figs. 6, 7a). Administration of NGF at a low dose had no significant effect on IB4 binding after axotomy and produced only a slight increase in TMP activity after axotomy $(p<$ 0.05 ; unpaired $t$ test; comparing NGF treatment with axotomy alone) (Figs. 6, 7a). NGF administration at a high dose had a small but significant effect in restoring TMP activity and IB4 binding (by $\sim 10-15 \%, p<0.05$; unpaired $t$ test comparing NGF treatment with axotomy alone) (Figs. 6, 7a). The effect of NGF on TMP activity within the dorsal horn was much less than that of GDNF $(p<0.001$; comparing GDNF with NGF treatment at both high and low doses).

CGRP immunoreactive terminals are normally present within laminae I and II of the dorsal horn, the region in which trkAexpressing DRG cells terminate (Averill et al., 1995; Molliver et al., 1995). After axotomy there was $\sim 60 \%$ reduction in CGRP immunoreactivity within the sciatic termination territory (Fig.
$7 a$ ), as determined by image analysis. Intrathecal treatment with NGF at either a low or high dose largely prevented this change ( $p<0.001$; unpaired $t$ test; comparing NGF treatment at either dose to no treatment) (Fig. 7a). GDNF treatment at a low dose had no significant effect on CGRP levels after axotomy $(p>0.05$; unpaired $t$ test). GDNF treatment at a high dose had a small $(\sim 10 \%)$ but significant rescue effect on CGRP levels $(p<0.05$; unpaired $t$ test; comparing GDNF treatment to no treatment).

The cholera toxin B subunit (CTB) binds to the GM1 receptor, which is selectively expressed by myelinated sensory afferents. CTB undergoes transganglionic transport by these afferents and so can be used to study A-fiber terminations within the dorsal horn of the spinal cord. In normal animals (Fig. 8), CTB-labeled terminals were present within lamina I and the deep laminae of the spinal cord (laminae III-IV). There were some terminals present in lamina IIi but very few labeled fibers were present in lamina IIo. Image analysis demonstrated that the ratio of labeling in lamina IIo to lamina III was extremely low $(0.003 \pm 0.0006)$ (Fig. 6b). Two weeks after axotomy, CTB was present throughout lamina II, including lamina IIo, and there was also more intense labeling within lamina I (Fig. 8). This change is accepted to indicate A-fiber sprouting into the superficial laminae (Woolf et al., 1992, 1995; Bennett et al., 1996b). There was a significant increase in the ratio of labeling within lamina IIo to lamina III (to $0.631 \pm 0.07$ after axotomy; $p<0.01$; unpaired $t$ test) (Fig. $7 b$ ). In animals that had received a 2 week intrathecal infusion of GDNF at a low dose, the A-fiber sprouting within lamina II was largely prevented (Fig. 8). Very few CTB-labeled terminals were present within lamina IIo. Quantitative image analysis demonstrated that the ratio of CTB staining between lamina IIo and lamina III after this treatment was $0.016 \pm 0.002(p<0.01$; unpaired $t$ test compared with no treatment) (Fig. $7 b)$. Treatment with GDNF at the higher dose was even more effective (the ratio of CTB staining between lamina IIo and lamina III was $0.007 \pm 0.003$, which was not significantly different from that seen in normal intact animals). The difference between untreated and GDNFtreated axotomized animals was highly significant $(p<0.001$; unpaired $t$ test) (Fig. $7 b$ ). The profuse CTB labeling that normally occurs within lamina I after axotomy also appeared to be prevented by GDNF treatment.

\section{Trophic factor effects on electrophysiological properties of axotomized C-fibers}

Axotomy produces a conduction velocity slowing in C-fibers; we investigated the efficacy of GDNF and NGF in reversing this change. The conduction velocity $(\mathrm{CV})$ distribution of $\mathrm{C}$-fibers projecting through the normal tibial nerve was unimodal, with a mean of $0.86 \pm 0.06 \mathrm{~m} / \mathrm{sec}$. After two weeks of axotomy, velocity was slowed to a mean of $0.68 \pm 0.03 \mathrm{~m} / \mathrm{sec}$, and this was significant ( $p<0.01$; unpaired $t$ test). This slowing was also apparent as a leftward shift in the cumulative sum plots of $\mathrm{CV}$ of units (Fig. 

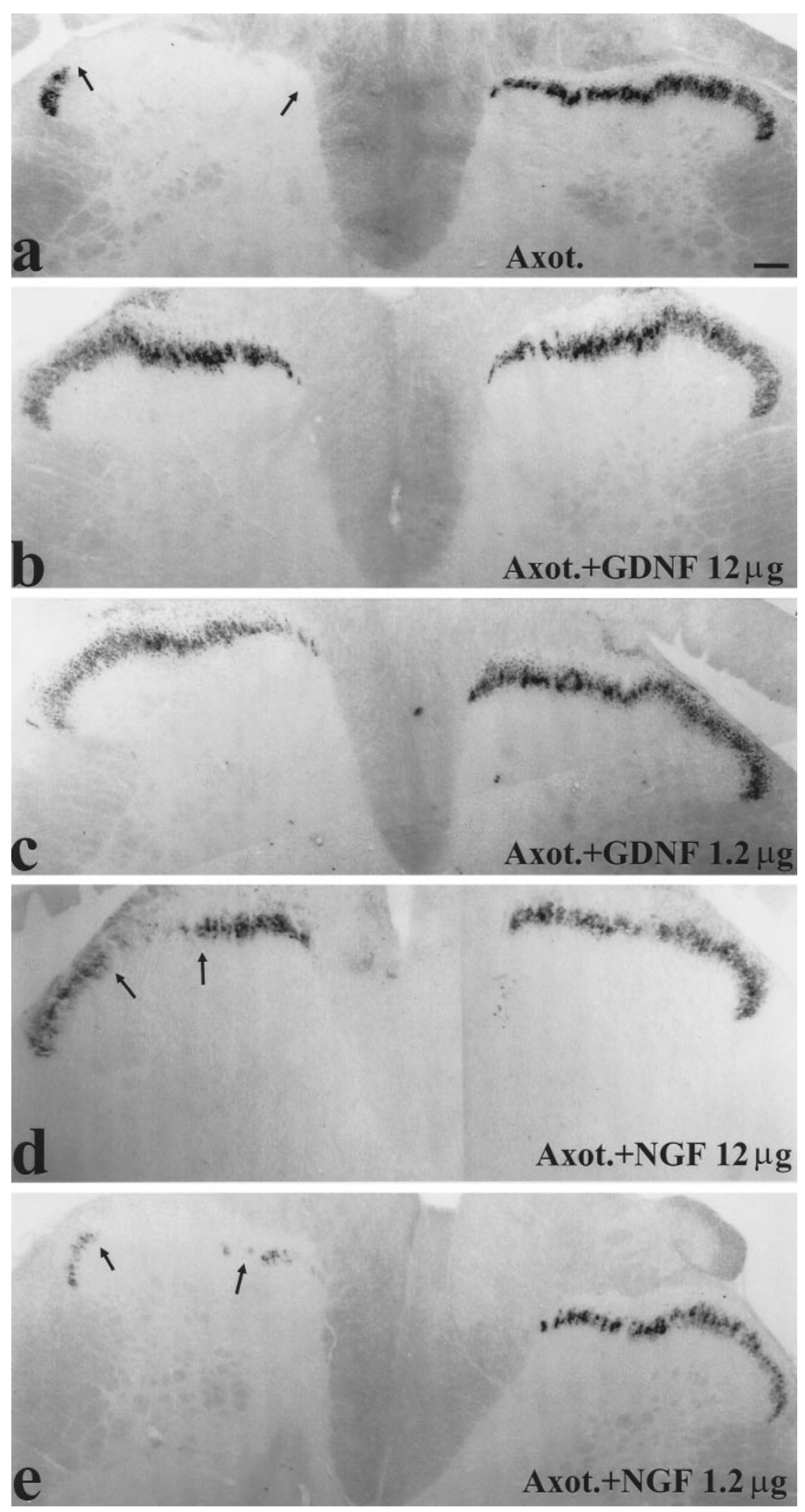

Figure 6. Histochemistry for TMP at the level of L4 in the dorsal horn of animals with unilateral sciatic nerve section $(a)$, animals with unilateral sciatic nerve section combined with high $(12 \mu \mathrm{g} / \mathrm{d})(b)$ and low $(1.2$ $\mu \mathrm{g} / \mathrm{d})(c)$ dose intrathecal GDNF treatment, and animals with unilateral sciatic nerve section combined with high $(12 \mu \mathrm{g} / \mathrm{d})(d)$ and low $(1.2 \mu \mathrm{g} / \mathrm{d})(e)$ dose intrathecal NGF. Sciatic nerve section causes a loss of TMP in the sciatic termination territory within lamina IIi (demonstrated by arrows). GDNF treatment at either dose is effective at preventing this loss $(b, c)$, whereas NGF is much less effective at either dose used $(d, e)$. Scale bar, $100 \mu \mathrm{m}$. Axot., Axotomized.
$9)$, and this shift was also statistically significant $(p<0.01$; Kolmogorov-Smirnov). Intrathecal provision of GDNF, at 12 $\mu \mathrm{g} / \mathrm{d}$, throughout the 2 week period of axotomy, partially and significantly prevented this slowing (Fig. 9) $(p<0.05$; Kolmogorov-Smirnov). The slowest conducting C-fibers were especially rescued by GDNF. NGF at $12 \mu \mathrm{g} / \mathrm{d}$ also had a partial and significant effect in preventing axotomy-induced slowing (Fig. 9) $(p<0.05$; Kolmogorov-Smirnov), although in this case C-fibers throughout the CV distribution were more equally affected, suggesting that GDNF and NGF do not affect the same population 

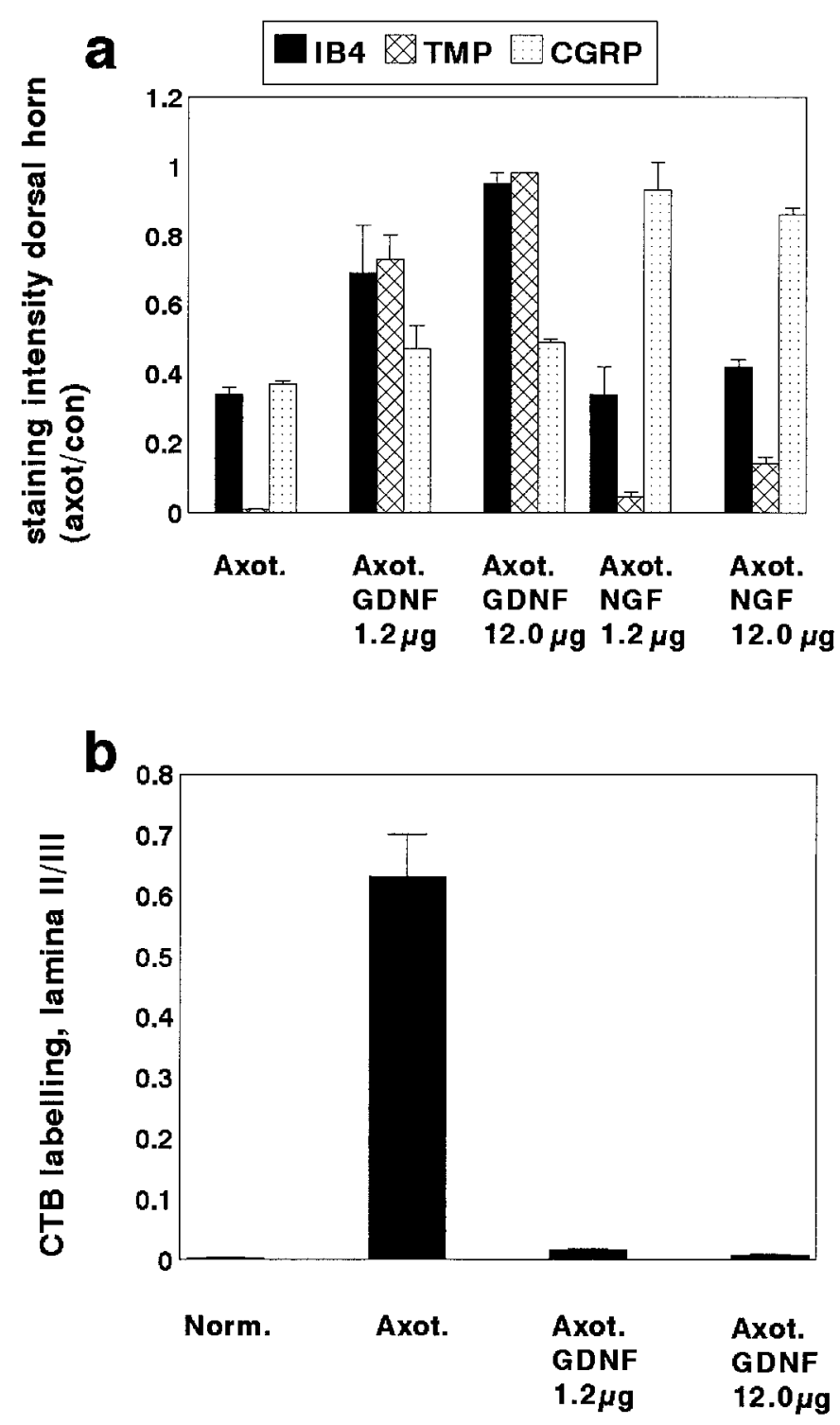

Figure 7. $a$, The ratio of the area occupied by IB4, TMP, or CGRP stained terminals within lamina II of the dorsal horn of the spinal cord on the axotomized side versus the normal side in animals that have undergone axotomy $(n=4)$ or axotomy in combination with an intrathecal infusion of GDNF at a dose of either $1.2 \mu \mathrm{g} / \mathrm{d}(n=3)$ or $12 \mu \mathrm{g} / \mathrm{d}(n=$ $4)$ or NGF at a dose of either $1.2 \mu \mathrm{g} / \mathrm{d}(n=3)$ or $12 \mu \mathrm{g} / \mathrm{d}(n=3)$. GDNF at a dose of $12 \mu \mathrm{g} / \mathrm{d}$ almost completely prevented the axotomy-induced reduction in staining intensity of IB4 and TMP $(p<0.001$; unpaired $t$ test; comparing GDNF with no treatment after axotomy). The lower dose of GDNF $(1.2 \mu \mathrm{g} / \mathrm{d})$ also had a significant effect in preventing the axotomy-induced reduction in staining intensity of these markers but was less effective than the higher dose. The high dose GDNF had a small but significant effect in preventing the axotomy-induced reduction in CGRP staining ( $p<0.05$; unpaired $t$ test). NGF could almost completely prevent the axotomy-induced reduction in CGRP staining $(p<0.001$; unpaired $t$ test; comparing NGF with no treatment after axotomy). NGF at $12 \mu \mathrm{g} / \mathrm{d}$ had a small but significant effect on the axotomy-induced reduction in IB4 and TMP expression ( $p<0.05$; unpaired $t$ test). $b$, The ratio of the area occupied by CTB-labeled terminals in lamina II compared with lamina III of the dorsal horn in normal $(n=5)$, axotomized $(n=4)$, and axotomy + GDNF (Axot. GDNF) $1.2 \mu \mathrm{g} / \mathrm{d}(n=3)$ and $12 \mu \mathrm{g} / \mathrm{d}(n=4)$ animals. Note that there is a significant increase in labeling in lamina II after axotomy ( $p<0.01$; unpaired $t$ test), which is almost completely prevented by treatment with GDNF at the higher dose. GDNF treatment at the low dose also had a significant effect $(p<0.01$ compared with no treatment; unpaired $t$ test) but was less effective than the higher dose. of afferents. Consistent with this suggestion, intrathecal provision of both NGF and GDNF, at $12 \mu \mathrm{g} / \mathrm{d}$ each, produced the greatest rescue of $\mathrm{C}$-fiber $\mathrm{CV}$. In fact, in this case neither the $\mathrm{CV}$ distribution nor the mean $\mathrm{CV}(0.83 \pm 0.03 \mathrm{~m} / \mathrm{sec})$ differed significantly from that seen in intact animals $(p>0.05$; Kolmogorov-Smirnov and unpaired $t$ test, respectively). Thus, these results provide an independent measure of the ability of GDNF and NGF, delivered by this route and at this dose, to produce a near-complete reversal of axotomy effects in C-fibers.

\section{DISCUSSION}

The principal conclusion of this work is that GDNF is a trophic factor for a substantial subgroup of adult primary sensory neurons that are neurotrophin independent. This conclusion is based on two lines of investigation: the localization of receptor components and the selective rescue effects of exogenous GDNF on axotomized sensory neurons, as discussed below.

\section{GDNF receptor component expression within sensory neurons}

The signal transducing domain of the GDNF receptor RET was found to be present in $60-70 \%$ of DRG cell profiles. GFR $\alpha-1$ and GFR $\alpha-2$, the ligand binding domains for GDNF and neurturin, had a more restricted distribution (they were expressed in 45 and $33 \%$ of DRG cell profiles, respectively). GDNF receptor components were strikingly expressed by the IB4 binding, trk-less population of DRG cells. Almost all IB4 cells express RET. Approximately $50 \%$ of IB4 cells also express GFR $\alpha-1$. This implies that $50 \%$ of IB4 cells coexpress both receptor components and are therefore likely to be highly sensitive to GDNF. The other $50 \%$ of the IB4 cells express RET, apparently in the absence of GFR $\alpha-1$. GDNF has been reported by some authors to be able to activate RET in the absence of GFR $\alpha-1$ and also to be able to act via the related neurturin receptor component GFR $\alpha$-2 (Baloh et al., 1997; Buj-Bello et al., 1997; Klein et al., 1997; Sanicola et al., 1997). We found that this receptor component was also highly localized within the IB4-binding population of DRG cells. In some cells it was coexpressed with GFR $\alpha-1$ and in others it was expressed independently of GFR $\alpha-1$. The majority (80\%) of IB4-binding DRG cells expressed either one or both ligand binding components. Therefore GDNF may be able to act on a larger population of IB4 cells than just those that express GFR $\alpha-1$. These findings also suggest that a proportion of the IB4-binding population of DRG cells are likely to be responsive to neurturin. RET immunoreactive terminals were found to project principally to lamina IIi of the dorsal horn of the spinal cord, the same lamina in which the IB4-binding DRG cells terminate. In contrast to the IB4 cells, the other population of small diameter DRG cells (those that express trkA) generally lack RET, GFR $\alpha-1$, and GFR $\alpha-2$. Any coexpression is largely accounted for by the known overlap between trkA and IB4 (18\% of trkA cells also bind IB4) (Averill et al., 1995). A significant number of large diameter DRG cells (as revealed by staining with N52) express GFR $\alpha$-1 or RET or both, suggesting that these cells may also be responsive to GDNF.

\section{Neuroprotective effects of GDNF on sensory neurons}

The receptor localization data discussed above shows that a large proportion of the "neurotrophin-independent" population of small diameter DRG cells express receptor components for GDNF. Markers that can be used to define this population include binding of the lectin IB4 and the enzyme TMP. A small subset of these cells also expresses the neuropeptide somatosta- 

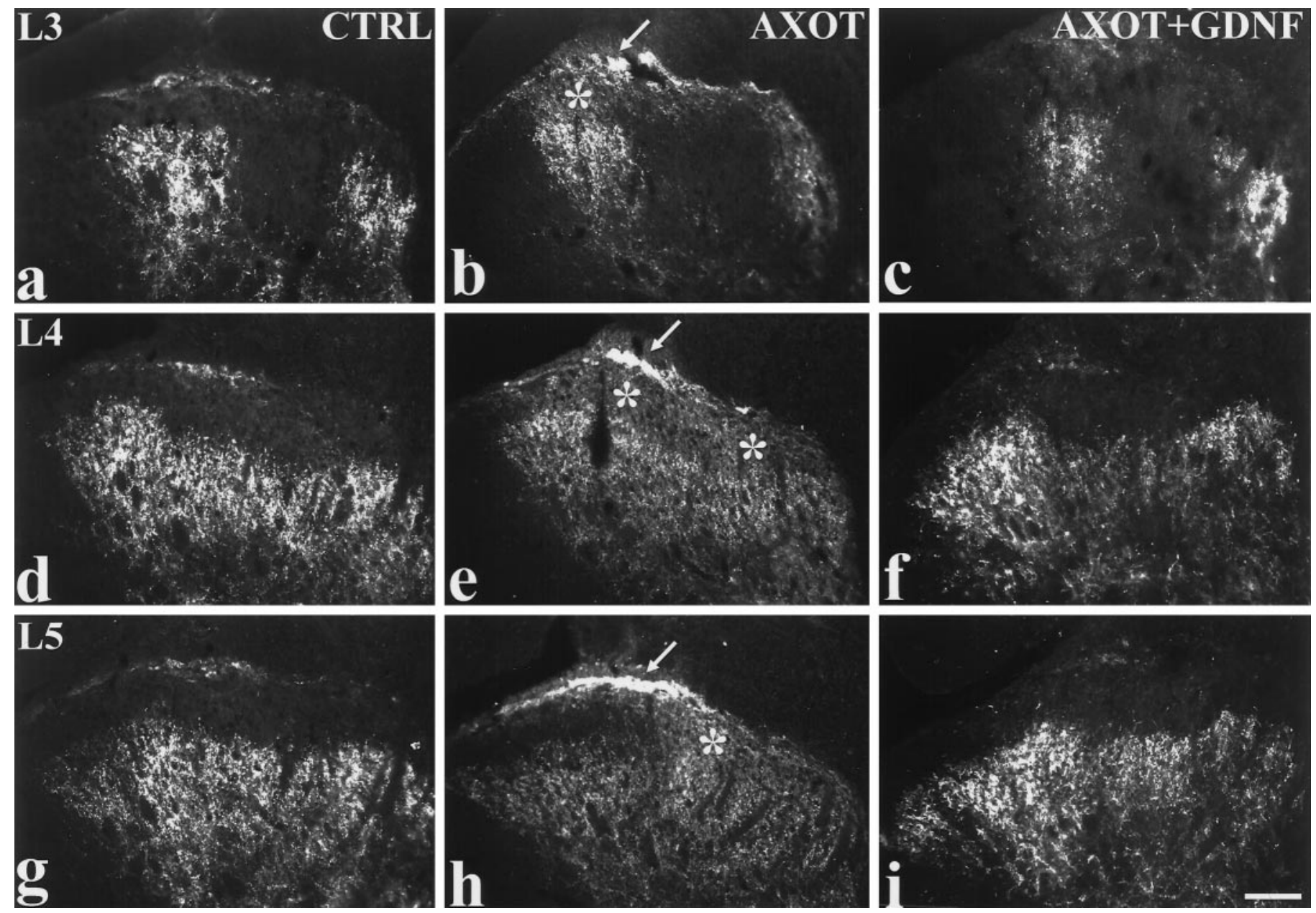

Figure 8. Transport of CTB to the dorsal horn of the spinal cord at the level of L3 $(a-c)$, L4 $(d-f)$, and L5 ( $g-i)$ after sciatic nerve label in control $(C T R L)$ animals $(a, d, g)$, animals that have undergone axotomy $(A X O T)(b, e, h)$, and animals that have undergone axotomy combined with GDNF $(A X O T+G D N F)$ treatment $(12 \mu \mathrm{g} / \mathrm{d})(c, f, i)$. In the normal animal, CTB-labeled terminals are present in lamina I and the deeper laminae of the dorsal horn (III-IV) but are excluded from lamina II $(a, d, g)$. After axotomy, CTB-labeled terminals appear in lamina II (denoted by asterisks), and there is also more dense labeling of axon bundles within lamina I (arrows in $b, e, h$ ). These axotomy-related changes are prevented by treatment with GDNF, where the CTB labeling pattern appears the same as control, and this is seen consistently throughout L3-L5 (c, $f, i)$. Scale bar, $100 \mu \mathrm{m}$.

tin. In this study we directly examined whether the IB4-binding population of sensory neurons would be responsive to GDNF (as compared with NGF) after axotomy. Intrathecal delivery was used, which we have previously demonstrated to be effective at delivering trophic factors to sensory neurons (Bennett et al., 1996b; Michael et al., 1997).

After axotomy we found that at both doses used, GDNF was much more effective than NGF at restoring IB4 binding, TMP staining, and somatostatin expression within both the DRG and the dorsal horn of the spinal cord. Conversely, NGF was much more effective than GDNF at restoring CGRP expression within the DRG and dorsal horn after axotomy. These findings complement those on receptor distribution. NGF has selective effects on the CGRP-expressing population of DRG cells, whereas conversely, GDNF has selective actions on the IB4-binding (i.e., neurotrophin-independent) population of cells. The known overlap between these markers (Averill et al., 1995) probably accounts for the limited nonselective effects seen. Our electrophysiological results provide an independent means of assessing the trophic effects of GDNF and NGF on small diameter DRG cells (Cfibers). GDNF and NGF appeared to prevent conduction velocity slowing after axotomy in distinct populations of $\mathrm{C}$-fibers, and importantly, the actions of these factors when administered together were additive. We have shown previously that conduction velocity slowing in large sensory neurons, induced by axotomy, is only marginally affected by intrathecal GDNF treatment (Munson and McMahon, 1997).

We have also demonstrated that GDNF could prevent the axotomy-induced A-fiber sprouting into lamina II of the dorsal horn. This may represent a direct effect of GDNF on large DRG neurons or it may occur as a consequence of the rescue effect of GDNF on IB4-binding small diameter DRG cells. There is now a body of evidence suggesting that degenerative atrophy of C-fiber terminals within lamina II after axotomy (Knyihar-Csillik et al., 1987) is critically important for A-fibers sprouting into this region. This evidence derives from the fact that $\mathrm{C}$-fibers in the sciatic nerve have a more restricted mediolateral and rostrocaudal distribution than sciatic A-fibers, and the sprouting of A-fibers occurs only in the termination region of axotomized C-fibers (Woolf et al., 1995). Furthermore, capsaicin, which selectively damages C-fibers, can induce A-fiber sprouting (Mannion et al., 1996). We have shown previously that NGF can prevent A-fiber sprouting (Bennett et al., 1996b), and the demonstration here that GDNF is also effective is likely to represent the "rescue" of the 
a

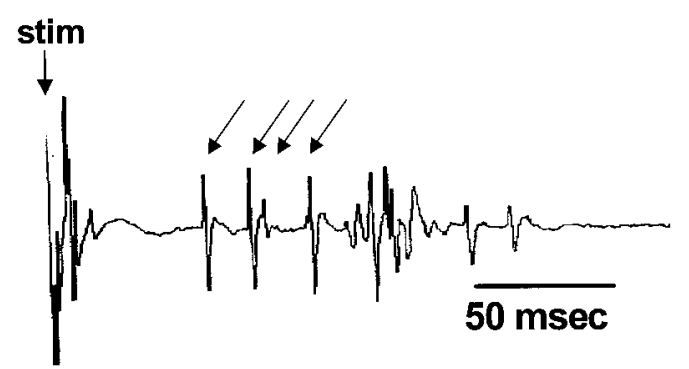

b

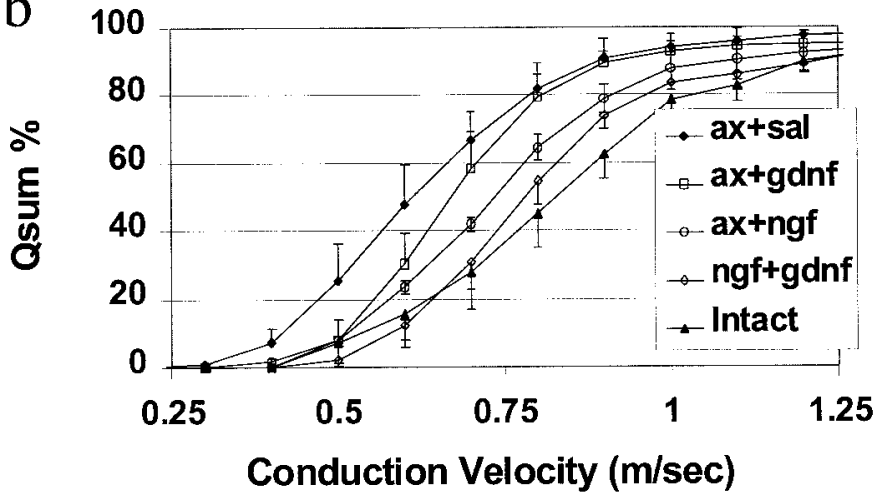

Figure 9. The conduction velocity $(\mathrm{CV})$ of $\mathrm{C}$-fibers projecting through the tibial nerve was measured by stimulation of that nerve electrically and recording and averaging activity in fine strands of the L5 dorsal root. $a$ shows a representative recording from an animal in which the tibial nerve had been cut and tied 2 weeks previously; the animal was treated continuously with intrathecal GDNF and NGF (each at $12 \mu \mathrm{g} / \mathrm{d}$ ). Arrows show examples of individual $\mathrm{C}$-fiber potentials occurring in response to the stimulation. $b$, Cumulative sum plots showing the average $\mathrm{CV}$ distributions constructed from groups of animals receiving different treatment ( $n=3-5$ animals per group). Error bars show SEM. Note that axotomy results in a significant slowing of C-fibers (seen as a leftward shift in the Qsum plots), and both NGF and GDNF partially prevent this slowing.

IB4-binding population of small diameter afferents after axotomy. These results are interesting in that, as we have demonstrated here, NGF and GDNF support largely separate populations of $\mathrm{C}$-fibers and yet either can prevent the sprouting response after axotomy.

\section{Functional implications of GDNF effects}

Our data indicate that GDNF has a potent and selective effect on the IB4-binding population of DRG cells, and similar selectivity has recently been observed in vitro (Molliver et al., 1997; Leclere et al., 1998). The IB4 population of primary afferents are primarily small in diameter. Given that $80-90 \%$ of C-fibers are nociceptors (Lynn and Carpenter, 1982; Kress et al., 1992), IB4-binding DRG cells must be principally nociceptive in function (Willis and Coggeshall, 1991). These neurons are capsaicin sensitive (Fitzgerald, 1983) and possess free nerve endings in various tissues, including skin, muscle, joint, and viscera. It has recently been shown that this group of sensory neurons selectively expresses the purinergic receptor $\mathrm{P}_{2} \mathrm{X}_{3}$ (Vulchanova et al., 1996). This receptor is thought to be important in mediating the nociceptive actions of ATP (Cook et al., 1997). The sensitivity of this population to GDNF suggests that this factor may be important in the development and maintenance of pain-signaling systems.

One important question is whether GDNF is normally required for the phenotypic maintenance of the IB4 population of
DRG cells or whether the rescue effects on these cells reflect a purely pharmacological action. GDNF is produced by peripheral targets (Trupp et al., 1995) and may normally be available to these afferents. It is unknown, as yet, whether neurturin also has actions on the IB4-binding population of DRG cells.

It is interesting that the IB4-binding population of DRG cells develops such marked sensitivity to GDNF during postnatal development. During embryonic development these neurons are dependent for survival on NGF and are absent in animals that lack trkA (Silos-Santiago et al., 1995). The developmental regulation of RET has been studied by Molliver et al. (1997) in the mouse. RET was only clearly seen in DRG cells from embryonic day 15. Expression increased in IB4 cells during the late embryonic and early postnatal period and reached the adult levels by approximately postnatal day 7. At the time RET is reaching its peak, the same neurons downregulate trkA and lose their NGF sensitivity (Bennett et al., 1996a; Molliver and Snider, 1997). Molliver et al. (1997) also reported a pattern of GFR $\alpha-1 /$ RET distribution similar to what we report here.

Nerve injury may result in abnormalities of sensation and importantly the generation of a chronic pain state in both animals and man. One important mechanism for these changes is the impaired retrograde transport of trophic factors after nerve injury (McMahon and Bennett, 1997). As a consequence of nerve injury, there is a large upregulation of GDNF expression within the damaged nerve (Trupp et al., 1995), as has been shown previously for NGF (Lindholm et al., 1987). Expression of GFR $\alpha-1$ has also been reported to increase in injured nerves (Baloh et al., 1997; Trupp et al., 1997), and this may act to present GDNF to regenerating neurons. Our results imply that the upregulation of GDNF expression in damaged nerves is not sufficient to prevent axotomy-induced changes.

The restitution of IB4 binding, TMP activity, and somatostatin expression by GDNF after axotomy may indicate a general beneficial action of GDNF in normalizing the properties of damaged sensory neurons. These anatomical findings were supported by the evidence that GDNF can partially prevent the conduction velocity slowing that occurs in a population of $\mathrm{C}$-fibers after axotomy. The A-fiber sprouting that occurs after axotomy has previously been implicated in the generation of some aspects of neuropathic pain. The suggestion is that when the large diameter, low-threshold mechanoreceptive A-fibers form synapses in lamina II with presumed pain-signaling postsynaptic dorsal horn systems, this provides an explanation for the condition of allodynia, or touch-evoked pain, that is frequently seen in neuropathic pain patients (Woolf et al., 1992).

Behavioral data suggest that GDNF can exert trophic effects on IB4 binding nociceptive afferents without altering their responses to acute noxious thermal and mechanical stimuli (D. L. H. Bennett and S. B. McMahon, unpublished observations). This is in marked contrast to the actions of NGF, which acts on the other major group of nociceptors, those expressing trkA. NGF acutely or chronically administered to animals and man can produce pain and hyperalgesia (Lewin et al., 1993; Petty et al., 1994; Woolf et al., 1994; Andreev et al., 1995). Because many forms of neuropathy in man affect small diameter nociceptive afferents, our results suggest that GDNF may be of some use in the treatment of these conditions. In particular, we would predict that GDNF may add to, rather than simply substitute for, the effects of NGF in the treatment of neuropathies. 


\section{REFERENCES}

Andreev NY, Dimitrieva N, Koltzenburg M, McMahon SB (1995) Peripheral administration of nerve growth factor in the adult rat produces a thermal hyperalgesia that requires the presence of sympathetic postganglionic neurones. Pain 63:109-115.

Averill S, McMahon SB, Clary SB, Reichardt LF, Priestley JVP (1995) Immunocy tochemical localization of trkA receptors in chemically identified subgroups of adult rat sensory neurons. Eur J Neurosci $7: 1484-1494$

Baloh RH, Tansey MG, Golden JP, Creedon DJ, Heukeroth RO, Keck CL, Zimonjic DB, Popescu NC, Johnson EM, Milbrandt J (1997) TrnR2, a novel receptor that mediates neurturin and GDNF signaling through Ret. Neuron 18:793-802.

Beck KD, Valverde J, Alexi T (1995) Mesencephalic dopaminergic neurons protected by GDNF from axotomy-induced degeneration in the adult brain. Nature 373:339-341.

Bennett DLH, Averill S, Clary DO, Priestley JV, McMahon SB (1996a) Postnatal changes in the expression of the trkA high affinity NGF receptor in primary sensory neurons. Eur J Neurosci 8:2204-2208.

Bennett DLH, French J, Priestley JVP, McMahon SB (1996b) NGF but not NT-3 or BDNF prevents the A fiber sprouting into lamina II of the spinal cord that occurs following axotomy. Mol Cell Neurosci 8:211-220.

Bowenkamp KE, Hoffman AF, Gerhardt GA, Henry MA, Biddle PT, Hoffer BJ, Granholm ACE (1995) Glial cell line-derived neurotrophic factor supports survival of injured midbrain dopaminergic neurons. J Comp Neurol 355:479-489.

Buj-Bello A, Buchman VL, Horton A, Rosenthal A, Davies AM (1995) GDNF is an age-specific survival factor for sensory and autonomic neurons. Neuron 15:821-828.

Buj-Bello A, Adu J, Pinon LGP, Horton A, Thompson J, Rosenthal A, Chinchetru M, Buchman V, Davies A (1997) Neurturin responsiveness requires a GPI-linked receptor and Ret receptor tyrosine kinase. Nature 387:721-724.

Canzian F, Ushijima T, Nagao M, Matera I, Romeo G, Ceccherini I (1995) Genetic mapping of the RET protooncogene on rat chromosome 4. Mamm Genome 6:433-435.

Cook SP, Vulchanova L, Hargreaves KM, Elde R, McCleskey EW (1997) Distinct ATP receptors on pain-sensing and stretch sensing neurons. Nature 387:505-508.

Durbec P, Marcos-Gutierrez CV, Kilkenny C, Grigoriou M, Wartiowaaria K, Suvanto P, Smioth D, Ponder B, Costantini F, Saarma M, Sariola H, Pachnis V (1996) GDNF signalling through the Ret receptor tyrosine kinase. Nature 381:789-793.

Fitzgerald M (1983) Capsaicin and sensory neurons: a review. Pain 15:109-130.

GFR $\alpha$ Nomenclature Committee (1997) Nomenclature of GPI linked receptors for the GDNF ligand family. Neuron 19:485.

Henderson CE, Phillips HS, Pollock RA, Avies A, Lemeulle C, Armanini M, Simmons L, Moffet B, Vandlen R (1994) GDNF: a potent survival factor for motoneurons present in peripheral nerve and muscle. Science 266:1062-1064.

Jing S, Wen D, Yu Y, Holst PL, Luo Y, Fang M, Tamir R, Antonio L, Hu Z, Cupples R, Louis JC, Hu S, Altrock BW, Fox GM (1996) GDNFinduced activation of the ret protein tyrosine kinase is mediated by GDNFR-alpha, a novel receptor for GDNF. Cell 85:1113-1124.

Kashiba H, Ueda Y, Senba E (1996) Coexpression of preprotachykinin-A, alpha-calcitonin gene-related peptide, somatostatin, and neurotrophin receptor family messenger RNAs in rat dorsal root ganglion neurons. Neuroscience 70:179-189.

Klein RD, Sherman D, Ho WH, Stone D, Bennett G, Moffat B, Vandlen R, Simmons L, Gu Q, Hongo J, Devaux B, Poulsen K, Armanini M, Nozaki C, Asai N, Goddard A, Phillips H, Henderson C, Takahashi M, Rosenthal A (1997) A GPI-linked protein that interacts with RET to form a candidate neurturin receptor. Nature 387:717-721.

Knyihar-Csillik E, Rakic P, Csillik B (1987) Transganglionic degenerative atrophy in the substantia gelatinosa of the spinal cord after peripheral nerve transection in rhesus monkeys. Cell Tissue Res 247:599-604.

Kotzbauer PT, Lampe PA, Heukeroth RO, Golden JP, Creedon DJ, Johnson EM, Milbrandt JD (1996) Neurturin a relative of glial-cellline-derived neurotrophic factor. Nature 6608:467-470.

Kress M, Koltzenburg M, Reeh PW, Handwerker HO (1992) Responsiveness and functional attributes of electrically localized terminals of cutaneous C-fibres in vivo and in vitro. J Neurophysiol 68:581-595.

Leclere PG, Ekstrom P, Edstrom A, Priestley JV, Averill S, Tonge DA
(1998) Effects of glial cell line-derived neurotrophic factor on axonal growth and apoptosis in adult mammalian sensory neurons in vitro. Neuroscience 82:545-558.

Lewin GR, Ritter AM, Mendell LM (1993) Nerve growth factorinduced hyperalgesia in the neonatal and adult rat. $\mathrm{J}$ Neurosci 230:2136-2148.

Lin LF, Doherty DH, Lile JD, Bektesh S, Collins F (1993) GDNF: a glial cell line-derived neurotrophic factor for midbrain dopaminergic neurons. Science 260:1130-1132.

Lindholm D, Heumann R, Meyer M, Thoenen H (1987) Interleukin-1 regulates synthesis of nerve growth factor in non-neuronal cells rat sciatic nerve. Nature 330:658-659.

Lynn B, Carpenter SE (1982) Primary afferent units from the hairy skin of the rat hind limb. Brain Res 238:29-43.

Mannion RJ, Doubell TP, Coggeshall RE, Woolf CJ (1996) Collateral sprouting of uninjured primary afferent A-fibers into the superficial dorsal horn of the adult rat spinal cord after topical capsaicin treatment of the sciatic nerve. J Neurosci 16:5189-5195.

Matheson CR, Garnahan J, Urich JL, Bocangel D, Zhang TJ, Yan Q (1997) Glial cell line-derived neurotrophic factor (GDNF) is a neurotrophic factor for sensory neurons: comparison with the effects of the neurotrophins. J Neurobiol 32:22-32.

McMahon SB (1986) The localization of fluoride-resistant acid phosphatase (FRAP) in the pelvic nerves and sacral spinal cord of rats. Neurosci Lett 64:305-310.

McMahon SB, Bennett DLH (1997) Growth factors and pain. In: Handbook of pharmacol 130 (Dickenson A, Besson J-M), pp 135-157. Berlin: Springer.

McMahon SB, Armanini MP, Ling LH, Phillips HS (1994) Expression and coexpression of Trk receptors in subpopulations of adult primary sensory neurons projecting to identified peripheral targets. Neuron 12:1161-1171.

Michael GJ, Priestley JV (1996a) Expression of trkA and p75 nerve growth factor receptors in the adrenal gland. NeuroReport 7:1617-1622.

Michael, GJ, Priestley JV (1996b) Combined immunocytochemistry and in situ hybridization. In: In situ hybridization techniques for the brain (Henderson Z, ed), pp 111-118. New York: Wiley.

Michael GJ, Averill S, Nitkunan A, Rattray M, Bennett DLH, Yan Q, Priestley JV (1997) Nerve growth factor treatment increases brainderived neurotrophic factor selectively in trkA-expressing dorsal root ganglion cells and in their central terminations within the spinal cord. J Neurosci 17:8476-8490.

Molliver DC, Snider WD (1997) Nerve growth factor receptor trkA is down-regulated during postnatal development by a subset of dorsal root ganglion neurons. J Comp Neurol 381:428-438.

Molliver DC, Radeke MJ, Feinstein SC, Snider WD (1995) Presence or absence of trkA protein distinguishes subsets of small sensory neurons with unique cytochemical characteristics and dorsal horn projections. J Comp Neurol 361:404-416.

Molliver DC, Wright DE, Leitner ML, Parsadanian AS, Doster K, Wen D, Yan Q, Snider WD (1997) IB4-binding nociceptors switch from NGF to GDNF dependence in early postnatal life. Neuron 19:849-861.

Moore MW, Klein RD, Farinas I, Sauer H, Armanini M, Phillips HS, Reichart LF, Ryan AM, Carver-Moore K, Rosenthal A (1996) Renal and neuronal abnormalities in mice lacking GDNF. Nature 382:76-79.

Munson JB, McMahon SB (1997) Effects of GDNF on axotomised sensory and motor neurons in adult rats. Eur J Neurosci 9:1126-1129.

Oppenheim RW, Houenou LJ, Johnson JE, Lin L-FH, Li L, Lo AC, Newsome AL, Prevette DM, Wang S (1995) Developing motor neurons rescued from programmed and axotomy-induced cell death by GDNF. Nature 373:344-346.

Petty BG, Cornblath DR, Adornato BT, Chaudhry V, Flexner C, Wachsman M, Sinicropi D, Burton LE, Peroutka SJ (1994) The effect of systemically administered recombinant human nerve growth factor in healthy human subjects. Ann Neurol 36:244-246.

Sanicola M, Hession C, Worley P, Carmillo P, Ehrenfels C, Walus L, Robinson S, Jaworski G, Wei H, Tizard R, Whitty A, Pepinsky R, Cate R (1997) Glial cell line-derived neurotrophic factor-dependent RET activation can be mediated by two different cell-surface accessory proteins. Proc Natl Acad Sci USA 94:6238-6243.

Silos-Santiago I, Molliver DC, Ozaki S, Smeyne RJ, Fagan AM, Barbacid M, Snider WD (1995) Non-TrkA-expressing small DRG neurons are lost in TrkA deficient mice. J Neurosci 15:5929-5942.

Silverman JD, Kruger L (1990) Selective neuronal glycoconjugate ex- 
pression in sensory and autonomic ganglia: relation of lectin reactivity to peptide and enzyme markers. J Neurocytol 19:789-801.

Treanor JJ, Goodman L, de Sauvage F, Stone DM, Poulsen KT, Beck CD, Gray C, Armanini MP, Pollock RA, Hefti F, Phillips HS, Goddard A, Moore MW, Buj-Bello A, Davies AM, Asai N, Takahashi M, Vandlen R, Henderson CE, Rosenthal A (1996) Characterization of a multicomponent receptor for GDNF. Nature 382:80-83.

Trupp M, Ryden M, Jornvall H, Funakoshi H, Timmusk T, Arenas E, Ibanez CF (1995) Peripheral expression and biological activities of GDNF, a new neurotrophic factor for avian and mammalian peripheral neurons. J Cell Biol 130:137-148.

Trupp M, Arenas E, Fainzilber M, Nilsson A-S, Sieber B-A, Grigoriou M, Kilkenny C, Salazar-Grueso E, Pachnis V, Arumae U, Sariola H, Saarma M, Ibanez CF (1996) Functional receptor for GDNF encoded by the c-ret proto-oncogene. Nature 381:785-788.

Trupp M, Belluardo N, Funakoshi H, Ibanez CF (1997) Complementary and overlapping expression of glial cell line-derived neurotrophic factor (GDNF), c-ret proto-oncogene, and GDNF receptor-alpha indicates multiple mechanisms of trophic actions in the adult rat CNS. J Neurosci 17:3554-3567.

Verge VM, Richardson PM, Wiesenfeld-Hallin Z, Hokfelt T (1995) Differential influence of nerve growth factor on neuropeptide expression in vivo: a novel role in peptide suppression in adult sensory neurons. J Neurosci 15:2081-2096.
Verge VM, Gratto KA, Karchewski LA, Richardson PM (1996) Neurotrophins and nerve injury in the adult. Philos Trans R Soc Lond B Biol Sci 351:423-430.

Vulchanova L, Riedl M, Shuster S, Wang J, Buell G, Surprenant A, North RA, Elde R, (1996) Immunohistochemical localization of the P2X3 receptor subunit in rat dorsal root ganglion (DRG) neurons. Soc Neurosci Abstr 22:1810.

Willis WD, Coggeshall RE (1991) Sensory mechanisms of the spinal cord, Ed 2. New York: Plenum.

Woolf CJ, Shortland P, Coggeshall RE (1992) Peripheral nerve injury triggers central sprouting of myelinated afferents. Nature 355:75-78.

Woolf CJ, Safieh-Garabedian B, Ma QP, Crilly P, Winter J (1994) Nerve growth factor contributes to the generation of inflammatory sensory hypersensitivity. Neuroscience 62:327-331.

Woolf CJ, Shortland P, Reynolds M, Ridings J, Doubell T, Coggeshall RE (1995) Reorganization of central terminals of myelinated primary afferents in the rat dorsal horn following peripheral axotomy. J Comp Neurol 360:121-134.

Wright DE, Snider WD (1995) Neurotrophin receptor mRNA expression defines distinct populations of neurons in rat dorsal root ganglia. J Comp Neurol 351:329-338.

Yan Q, Matheson C, Lopez OT (1995) In vivo neurotrophic effects of GDNF on neonatal and adult facial motor neurons. Nature 373: 341-344. 